This item was submitted to Loughborough's Research Repository by the author.

Items in Figshare are protected by copyright, with all rights reserved, unless otherwise indicated.

\title{
Conceptual model of partnering and alliancing
}

PLEASE CITE THE PUBLISHED VERSION

http://dx.doi.org/10.1061/(ASCE)0733-9364(2007)133:3(225

\section{PUBLISHER}

(C) American Society of Civil Engineers (ASCE)

\section{VERSION}

AM (Accepted Manuscript)

LICENCE

CC BY-NC-ND 4.0

\section{REPOSITORY RECORD}

Anvuur, Aaron M., and Mohan M. Kumaraswamy. 2019. "Conceptual Model of Partnering and Alliancing". figshare. https://hdl.handle.net/2134/12346. 
This item was submitted to Loughborough's Institutional Repository (https://dspace.lboro.ac.uk/) by the author and is made available under the following Creative Commons Licence conditions.

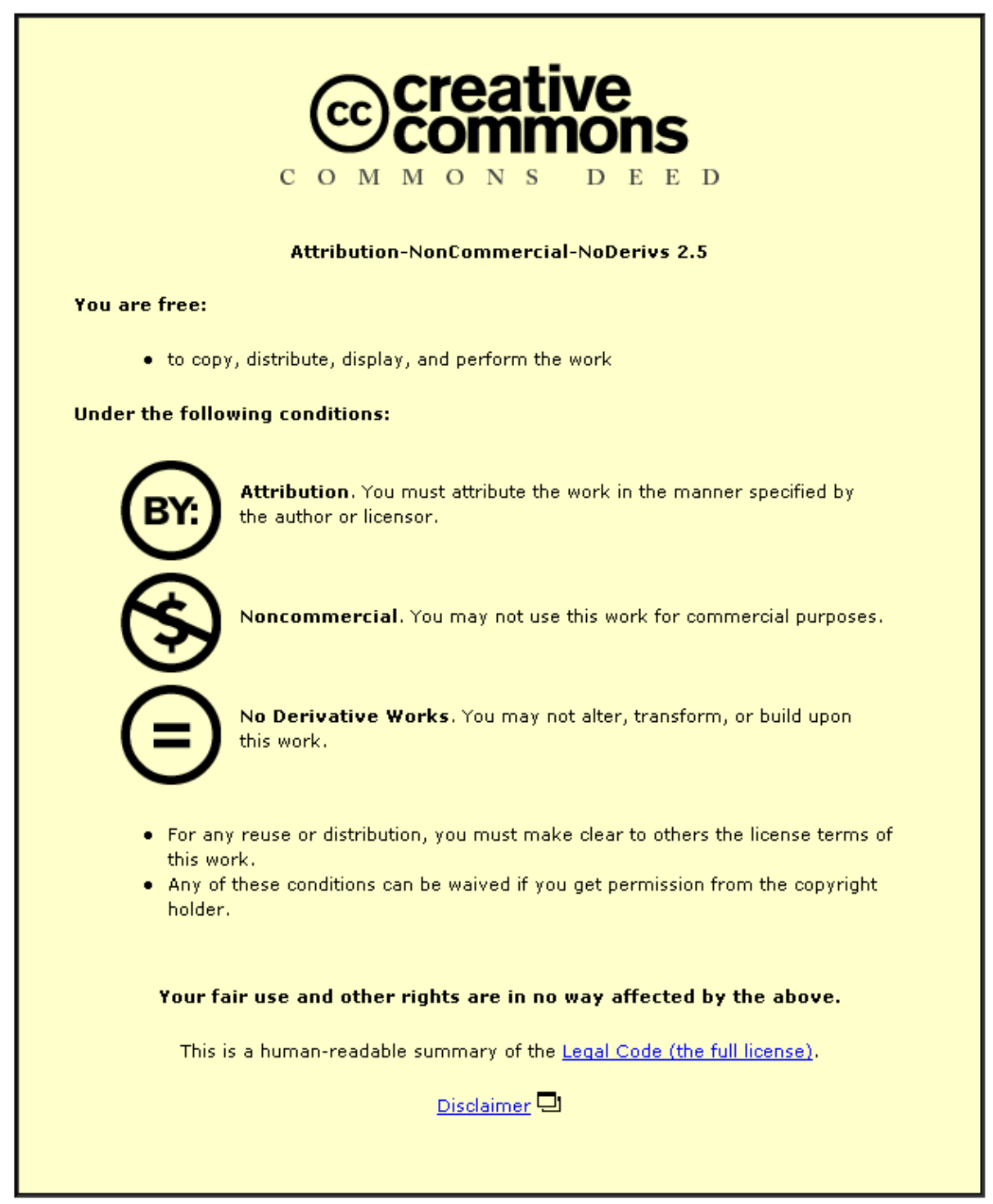

For the full text of this licence, please go to: http://creativecommons.org/licenses/by-nc-nd/2.5/ 


\title{
Conceptual model of partnering and alliancing ${ }^{1}$
}

\author{
Aaron M. Anvuur and Mohan M. Kumaraswamy, M.ASCE
}

Partnering as a concept has matured in its application and many empirical studies provide evidence of its impact on project performance beyond the rather prescriptive and anecdotal claims of earlier cookbooks on the subject. What has remained elusive, however, is a guiding theory on partnering. Drawing on the literature, partnering is explained within the framework of intergroup contact theory and teamwork in organizations. More specifically, partnering has the potential to create the essential conditions for optimal intergroup contact and hence, to reduce bias and increase cooperation among construction project workgroups and, consequently, favorably impact on project performance. Demonstrating a close fit with the published literature on partnering provides useful support for the proposed model. The model can clearly help project managers to focus their attention on the necessary aspects of workgroup processes that lead to high cooperation and performance.

CE Database subject headings: Alignment; Cooperation; Partnerships; Teamwork.

\footnotetext{
${ }^{1}$ This is the pre-publication version of Anvuur and Kumaraswamy (2007) published in Journal of Construction Engineering and Management, 133(3), 225-234. The publisher version is available at the ASCE Civil Engineering Database (http://dx.doi.org/10.1061/(ASCE)0733-9364(2007)133:3(225))
} 


\section{Introduction}

Over the last decade, partnering has gained considerable popularity. However, several issues raise serious difficulties with the uptake of, understanding of, approach to, and implementation of, partnering within and across different national and organizational settings (Loraine, 1994; Green, 1999; Uher, 1999; Bresnen and Marshall, 2000a; Bresnen and Marshall, 2000b; Li et al., 2000; Fisher and Green, 2001; Bresnen and Marshall, 2002; Naoum, 2003). In time, research has shed light on some of the contentious issues surrounding the concept of partnering. A number of empirical studies (e.g., Weston and Gibson, 1993; Larson, 1995; Gransberg et al., 1999) and a plethora of anecdotal evidence support the espoused benefits of partnering. Research highlights the usefulness and benefits of extending the practice of partnering down the entire supply and value chain to include subcontractors (e.g., Mathews et al., 1996; Love, 1997; Kale and Arditi, 2001; Miller et al., 2002; Sze et al., 2003). Partnering forms of contract (e.g., PPC 2000) attempt to prescribe and govern the behavior and relationships of contracting parties. While the legal status of such express good faith clauses has been questioned and their full practical import is yet unknown (see Cornes, 1996; Cox and Thompson, 1996), these attempts demonstrate a bold commitment to overcome the legal obstacles to the wider adoption of partnering. Some research has considered the potential impact of different cultural and national contexts on partnering performance (e.g., Kwan and Ofori, 2001; Liu and Fellows, 2001; Koraltan and Dikbas, 2002). With 'success stories' of partnering emerging from diverse cultural settings (e.g., Bennett and Baird, 2001; Bayliss et al., 2004; Chan, Chan, Fan et al., 2004), the general view is that partnering is by no means exclusive to any country, continent or culture. 
However, partnering still lacks conceptual-definitional specificity. Partnering is variously defined by its outcomes or the processes involved in its implementation (Crowley and Karim, 1995). Barlow et al. (1997) and the ECI (1997) avoid attempting a precise definition and instead conclude that partnering is best considered as embodying a set of processes and practices designed to promote cooperation between contracting parties. According to Phua and Rowlinson (2004b: 45), partnering is the term for the cooperation motif in the construction industry. Love et al. (2002: 2) conclude that partnering is synonymous with strategic alliance. Nyström (2005: 473) concludes that 'a definition does not exist for this multifaceted concept'. It is argued that the confusion over definitions is due primarily to the lack of a guiding theory on partnering as an entity. Existing conceptual models of partnering to date (a) are cookbooks on the concept (i.e. process models) providing guidance on best practices and 'how to' (e.g., Wilson Jr et al., 1995; Brooke and Litwin, 1997; Crane et al., 1997; Cheng and Li, 2001), (b) describe and/ or categorize various stages in the development of the relationship amongst the parties (e.g., Ellison and Miller, 1995; Thompson and Sanders, 1998; Nyström, 2005) or (c) describe the facilitating structure for resource exchange and decision-making amongst the parties (e.g., Crowley and Karim, 1995; Cheng et al., 2001). While significant, these studies fail to provide sound theoretical support for the entity of partnering and, the recommendations and observations they make.

It is in this area that this paper hopes to make a useful contribution - in providing sound theoretical support for the processes and elements that define the entity of partnering. The rest of the discussion is organized as follows. The next section describes the 
industry context, which gave rise to the notion of partnering. The two sections that follow discuss, respectively, the theory of teamwork in organizational settings and the contact hypothesis, as underpinning the partnering philosophy. Drawing on these theories, a model for partnering is proposed. The essential factors for, and processes in, partnering are then discussed. Evidence from the partnering literature is used for the preliminary validation of the proposed model. The paper concludes with some recommendations and directions for future research.

\section{The industry context}

Differentiation in the construction industry, especially subcontracting, is a response to uncertainty arising from complexity (Eccles, 1981b). This creates a situation of interdependence, which makes cooperation crucial to the success of construction projects. This complexity, uncertainty and interdependence have significant implications for the organization, control and coordination of construction projects (Eccles, 1981b; Gidado, 1996; Shirazi et al., 1996; Dubois and Gadde, 2002; Winch, 2003). Typically, construction coping strategies, e.g., competitive tendering, arms-length contracts incorporating manipulative performance incentive and, industry 'communities of practice', allowed these complexity and uncertainty dimensions to be addressed while guarding against opportunistic behavior (Bradach and Eccles, 1989; Dubois and Gadde, 2002).

As project complexity and uncertainty intensify (e.g., due to sophistication of human needs, technological advances, market pressures), extensive subcontracting ensues and 
interdependence deepens. These coping strategies soon become erosive in nature. Zerosum competitive tendencies, arising from the market extent and increased differentiation, soon lead to fragmentation and adversarial relationships. Contracts are more complex and are routinely written or amended to exclude or transfer liability. As the focus shifts to the contract, short-term productivity (i.e. performance quantity) is favored over the long-term sustainability and quality considerations and, innovation suffers (Thompson et al., 1998; Dubois and Gadde, 2002).

Over time, these negative relationships and attitudes have become institutionalized (i.e., affective priming) and, arguably, part of the culture of construction (Egan, 1998; CIRC, 2001). This has resulted in stereotyping (of each other and professions), and even prejudice, among the various stakeholders (i.e., cognitive priming), which then constrains future relationships (Moore and Dainty, 2001). This adversarial culture has been partly blamed for the poor uptake of new processes and management strategies in the construction industry (Bresnen and Marshall, 2001). It is in this context that the idea of partnering was conceived and introduced. Partnering thus provides a promise of cooperation in an industry setting where commercial pressures traditionally encourage reticence, caution and even adversarial relationships. But just how does partnering achieve this? The next two sections discuss two theories put forward in this paper as the conceptual bases for partnering. 


\section{The team approach in organizations}

Construction is considered largely as a 'team' industry (Turner, 1997; Love et al., 1998;

Holti et al., 1999; Anumba et al., 2002; Male, 2002). It is usual for the representatives of the client, consultants and constructors on a construction project to be called the 'project team'. However, these are workgroups and do not necessarily become teams because someone calls them so (Katzenbach and Smith, 1993; Albanese, 1994; Fleming and Koppelman, 1996; Ingram et al., 1997; Schermerhorn et al., 1998). In order to avoid confusion terms like integrated project team, though tautological, are now gaining prominence in usage (SFC, 2003; Baiden et al., 2006). Katzenbach and Smith (1993: 112) defines a team as 'a small number of people with complementary skills who are committed to a common purpose, set of performance goals, and approach for which they hold themselves mutually accountable'.

The characteristics of optimal teams can be summarized as follows (West, 1990; Katzenbach and Smith, 1993; Albanese, 1994; Ingram et al., 1997; Anderson and West, 1998; Chow et al., 2005): (a) unitary focus and common goals; (b) interdependence, i.e. mutual respect, equal status and equal opportunities for participation; (c) mutual accountability, i.e. common fate and a 'no blame' culture; and (d) confluence, i.e. cohesion, seamless operation. These characteristics do not emerge easily. They are the results of the long and, sometimes difficult interactions through which the members (a) cultivate collective understandings of the membership and nature of the task and, (b) negotiate and shape their purposes in response to the demand or challenge. This commitment-building process ultimately leads to the establishment of a social contract 
that binds the membership to a common purpose and approach (Schein, 1980; Katzenbach and Smith, 1993). Effective teams translate their shared purpose into specific performance goals and targets and periodically assess their joint performance against these targets. These outputs typically include both individual and "collective work products' (Katzenbach and Smith, 1993). Mutual accountability grows out of the shared goals and cooperative interdependence engendered through the interactions of members (Johnson and Johnson, 2003).

Task interdependency is a pre-requisite (Shaw, 1981; Anderson and West, 1998). Members need to be selected on the basis of complementary technical/functional expertise and personality traits. Active training, expert facilitation and coaching facilitate this commitment-building process (Drew and Coulson-Thomas, 1996). Top management support must be both articulated and enacted. Without it, any sense of sharedness the team may develop will be largely subversive in character (West, 1990; Anderson and West, 1998). Confluence is a gestalt concept in which the boundaries of the self and the team merge. It is the optimal team climate for high performance and innovation (Reichers and Schneider, 1990; Anderson and West, 1998). Anderson and West (1994) define team climate as 'the norms, atmosphere, practices, interpersonal relationships, enacted rituals and ways of working developed by a team'. Confluence manifests itself in the cohesion, synergy and high performance of the team (Syer and Connolly, 1996). It is the result of the long and, often, painful commitment-building process through which the team evolves and learns, particularly from its failures and successes (Katzenbach and Smith, 1993). 
The benefits of teamwork include, among others, breaking down barriers to effective communication and establishing cross-functional cooperation (Pinto and Pinto, 1990; Albanese, 1994; Drew and Coulson-Thomas, 1996), which leads to trust and commitment (Katzenbach and Smith, 1993) and, high performance and innovation (Lampman and Dimeo, 1989; Pinto and Pinto, 1990; Todryk, 1990; Katzenbach and Smith, 1993; Albanese, 1994; Fleming and Koppelman, 1996).

\section{The Contact Hypothesis}

Researchers in social psychology have, for many years, studied the subject of prejudice and bias in intergroup contact situations to understand their causes and to develop effective strategies for mitigating them. An understanding of how such intergroup bias and conflict arises is provided by Tajfel's $(1978,1982)$ and Tajfel and Turner's (1979) work on social categorization and social identity theory. According to these theories, categorization of people into distinct groups is sufficient in itself to create intergroup bias in business as well as social settings. In addition, factors that increase intergroup bias tend to increase the saliency of the categorized representation. According to Tajfel and Turner (1979), an individual's need for positive self-identity motivates social comparisons that favorably differentiate ingroup from outgroup members. Ingroup members are viewed as being very similar to self, are evaluated more positively and receive greater pro-social (i.e. helping) behavior than outgroup members. Such bias, however, leads to ingroup favoritism but, not necessarily, to outgroup discrimination (Gaertner et al., 2000). Support for these theories is also available in the context of construction (see Phua, 2004; Phua and Rowlinson, 2004a). A possible solution is 
therefore to seek strategies that could alter the categorization of ingroup and outgroup memberships.

At the core of this research effort is the contact hypothesis (Allport, 1954). According to Allport (1954), four key conditions are essential for optimal (i.e. positive) intergroup contact: (a) equal group status within the contact situation; (b) common goals; (c) intergroup cooperative interaction; and (d) support of authorities, law or custom. Field, archival, survey and laboratory research, in different organizational and social settings, supports the contact hypothesis (see Sherif and Sherif, 1966; Pettigrew, 1998; Gaertner and Dovidio, 2000). Pettigrew (1998) identifies four distinct but interrelated processes that operate through contact and mediate change: (a) learning about the outgroup; (b) changing behavior; (c) generating affective ties; and (d) ingroup reappraisal. It is these processes that create the sense of sharedness that reduces bias and promotes cooperation. Optimal intergroup contact requires time and repeated contact to achieve as it is related to the extent to which groups learn (Sherif and Sherif, 1966).

Institutional and societal norms structure the form and effects of contact situations. According to Wilner et al. (1955), quoted in Pettigrew (1998: 68), 'contact and perceived social climate tend to reinforce each other when their influence operates in the same direction, and to cancel each other out when their influence works in the opposite direction.' If present, such normative support also makes the attainment of other optimal contact conditions easier (Pettigrew, 1998; Gaertner and Dovidio, 2000). Also, prior experiences and attitudes influence contact effects so that people with favorable prior experience of contact are more likely to seek, and those with bad experiences are more 
inclined to avoid, future contact (Pettigrew, 1997; Pettigrew, 1998). Positive events that may lead to mood elevation, like rewards associated with intergroup cooperative interaction or success, in turn lead to broader and more inclusive categorization (Gaertner et al., 1993; Gaertner and Dovidio, 2000).

\section{What partnering does?}

The convergence of ideas from these hitherto related but separate lines of literature is remarkable. Taken together, they spell out what should be the essential factors for optimal project workgroup relationships in construction: (1) equal status or respect; (2) common goals; (3) cooperative workgroup interaction; and (4) support of the authorities and egalitarian norms. Confluence, optimal intergroup contact or good 'project chemistry' (see Nicolini, 2002), relates to how the team learns over time from failures and successes and is therefore an outcome of workgroup processes. These lines of literature clarify the context in which partnering in construction should be viewed and understood. It is argued that partnering is a change mechanism for transforming a crossfunctional project workgroup into a team. In other words, partnering has the potential to create the essential conditions for optimal contact between cross-functional project workgroups. Thus, rather than pre-existing the partnering relationship, these essential factors are the outcomes of successful partnering (see also Mosley et al., 1991; Cowan et al., 1992; Moore et al., 1992). Albanese (1994) refers to these essential factors or outcomes of successful partnering as process benefits. These process benefits are the vehicle through which the content benefits (e.g., cooperation, improved performance and innovation) are achieved. 
Based on the foregoing, Figure 1, adapted from the common ingroup identity model of Gaertner et al.'s (1993), has been developed to present a model of partnering and its consequences on cooperation and project performance outcomes. The left hand column of Figure 1 depicts the dominant industry conditions, as discussed earlier, that are the genesis of the notion of partnering. The second column outlines the key components of partnering that are important in helping project workgroups attain the essential conditions for optimal contact. When attained, these essential factors (see the third column of Figure 1) transform a workgroup into a high-performing team. The right hand column depicts the benefits or consequences of partnering. While the focus in construction research has been mainly on demonstrating the content benefits of partnering (e.g., outcomes on cost, quality and schedule) as its focal selling aspect, it is important to also note the many mediating cognitive and affective processes (e.g., trust, positive affect) involved (Gaertner et al., 1993; Pettigrew, 1998). The next section explains, on the basis of the proposed model, the key components of partnering practice and their importance.

\section{Explaining the key components of partnering practice}

The key components of partnering practice include (Hellard, 1995; Schultzel and Unruh, 1996; Thomas and Thomas, 2005): workshops and champions' meetings; charters and decision-making procedures; incentives; and periodic performance evaluation. These are explained in light of the proposed theory on partnering. 


\section{Workshops and champions' meetings}

The partnering workshops and periodic champions meetings provide opportunities for project workgroups to interact in a cooperative and non-threatening environment. These interactions kick-start the process of learning about and understanding one another's interests and concerns, which ultimately enables the project actors to collectively create, shape and own a set of common goals and approach for the project (Katzenbach and Smith, 1993; Pettigrew, 1998). Senior management's expression of support for this process is crucial for its success. Selecting members with the necessary technical or functional expertise is important not least because competence strongly predicts task performance (Motowidlo and Van Scotter, 1994) and trust (Das and Teng, 1998), both key outcomes as depicted in Figure 1. Training, expert facilitation and coaching help this process by encouraging honest and frank communication and problem solving in workgroups (Katzenbach and Smith, 1993; Drew and Coulson-Thomas, 1996). The champions' meetings serve to perpetuate this commitment-building or re-alignment process throughout the life of the project.

\section{Charters and problem-solving procedures}

Arguably, the problem in construction is a lack of recognition, rather than the absence, of task/functional interdependence. This fragmentation is a direct result of the industry context described earlier. Partnering thus seeks to force recognition of interdependence. The partnering charter and the joint decision-making procedures, otherwise called 'issue escalation ladder', provide testament to a joint recognition of interdependence by the project workgroup members. They are a testament to the social contract that binds the project workgroup to develop, and commit to, a common purpose and approach for 
achieving the project. The issue escalation ladder provides a mechanism for ensuring and sustaining cooperative interaction and for channeling controversy productively, however divisive members' differences may be. Mutual accountability grows naturally out of working together with a common purpose, goals and approach (Katzenbach and Smith, 1993; Pettigrew, 1998).

Top management support is required to reinforce the commitment-building process among project workgroup members. This support must be both articulated and enacted. Using partnering forms of contract or incorporating partnering-friendly amendments into traditional contracts also provides articulated support. Probably even more important is the provision of enacted support for cooperation, which includes some budget authority and authority to make technical decisions (or 'do deals') independent of direct functional interference. Such support is vital for successful implementation of the popular principle of resolving disputes at the lowest possible level and, is a key feature that distinguishes teams from committees (West, 1990; Anderson and West, 1998). Without the necessary authority support, teams function as committees (Fleming and Koppelman, 1996) and any shared goals, approach or climate developed will be largely subversive in character (Pettigrew, 1998; Gaertner and Dovidio, 2000).

\section{Team incentives}

Rewards associated with pleasant cooperative interaction or successes enhance mutual attraction and lead to more favorable and inclusive categorization of the workgroup memberships (Gaertner et al., 1993; Drew and Coulson-Thomas, 1996). These rewards range from very simple things like barbecues, field trips or official recognition of 
achievement in project newsletters and electronic mail, to the sharing of bonuses for achieving or exceeding performance targets. These team incentive arrangements usually operate independently of any performance incentives in the underlying legal contracts between the parties. One (relatively) successful application of team incentives in construction is in project alliancing. Project alliancing is, probably, best described as a deeper form of partnering, which contractually links the financial success of each of the parties directly to the overall success of the project.

The alliance agreement is drawn up as an overarching legal agreement (Halman and Braks, 1999; Barlow, 2000; Naoum, 2003) or constitutes the sole contract (Hauck et al., 2004; Rowlinson et al., 2006), which binds the parties to agreed targets, risk sharing and reward mechanisms. In the former arrangement, the underlying individual traditional contracts between the client and the suppliers gives the client the option of continuing the project conventionally should the alliance agreement fail (Halman and Braks, 1999; Barlow, 2000). However, in both arrangements the Alliance Agreement provides both articulated and enacted support for cooperation by creating, and facilitating the development of, a deepened and real, as opposed to a notional, sense of joint/ common fate (Halman and Braks, 1999; Barlow, 2000; Bower and Merna, 2002; Hauck et al., 2004; Rowlinson et al., 2006). These are essential factors in achieving team cohesion or confluence as shown in Figure 1.

\section{Periodic performance assessments}

Translating its common purpose into specific performance goals and associated targets allows the team to chalk up small successes as it pursues its broader purpose 
(Katzenbach and Smith, 1993). The mutuality, specificity, clarity, measurability and attainability of these performance goals and targets are therefore crucial (Locke and Latham, 1990; Katzenbach and Smith, 1993; Liu and Fellows, 2001). These are typically addressed during the value management sessions organized as part of the initial partnering workshops and reinforced during follow-up workshops and champions' meetings. These goals facilitate communication and constructive controversy and are 'symbols of accomplishment that motivate and energize' (Katzenbach and Smith, 1993: 113). Periodic performance assessments provide vital feedback in real time, which facilitates group learning and improvement to influence future performance (Katzenbach and Smith, 1993). Sherif and Sherif's (1966) infamous Robbers' Cave field experiment showed that effectiveness related to the extent to which the groups learn from successes and failures in intergroup cooperation and rivalry. Although this sort of learning is attempted during initial partnering workshops through resource dilemma games, the consequences of real life successes and failures are both graphic and compelling.

\section{Validation of model of partnering}

Varied research in construction supports the proposed model. These include industry sponsored research into partnering (e.g., CII, 1991; Bennett and Jayes, 1995; Lenard et al., 1996; Chan, Chan, Fan et al., 2004), as well as general research on partnering (e.g., Cook and Hancher, 1990; Larson and Drexler, 1997; Conley and Gregory, 1999; Black et al., 2000; Cheng et al., 2000; Glagola and Sheedy, 2002; Ng et al., 2002; Chan, Chan, Chiang et al., 2004; Fisher, 2004), alliancing (Barlow et al., 1997; Halman and Braks, 1999; Barlow, 2000; Hauck et al., 2004; Rowlinson et al., 2006) and relational 
contracting (e.g., Hampson and Kwok, 1997; Davis, 1999; Rahman and Kumaraswamy, 2002). Many studies also highlight the roles of partnering as a team-building mechanism and as a catalyst for cultural change (e.g., Mosley et al., 1991; Moore et al., 1992;

Abudayyeh, 1994; Albanese, 1994; Brown, 1994; Wilson Jr et al., 1995; Miles, 1996;

Gardiner and Simmons, 1998; Winch, 2000; Nicolini, 2002; Beach et al., 2005).

However, these studies also create problems, which stand in the way of uniform

understanding of the partnering concept. These issues are next discussed and clarified in the context of the proposed model of partnering in Figure 1.

\section{Partnering critical success factors and outcomes}

Rockart (1982: 4) defines critical success factors as 'those few key [factors] absolutely necessary to reach goals'. It is clear from this definition that any study of critical success factors without conceptual-definitional clarity is likely to be counterproductive. Many of the research studies on partnering mention one or more of the essential factors for optimal contact listed in Figure 1 as critical success factors for partnering. From the foregoing, it is clear that these cannot be critical success factors for partnering. Rather, they are the outcomes or process benefits of successful partnering. Partnering is the mechanism through which these conditions for optimal contact are induced and nurtured. Thus, taken to an extreme, partnering may well be viewed as an experiment in social psychology. Adopting a critical success factors perspective, and as argued in this paper, these factors are critical success factors for optimal cross-functional workgroup cooperation. 


\section{The role of trust}

Numerous studies mention trust and/or its correlates as critical success factors for partnering (e.g., Larson and Drexler, 1997; Black et al., 2000; Cheng et al., 2000;

Fisher, 2004). However, as indicated in the consequences section (top, right) of Figure 1, trust is a secondary outcome of partnering. In other words, trust need not pre-exist the partnering relationship. As indicated in the pre-contact experience box (bottom, left) of Figure 1, trust can pre-exist a partnering relationship and, may result from previous favorable contact experiences or representations (Pettigrew, 1998), or it may be spontaneous, resulting from 'faith in humanity' (McKnight et al., 1998). When present, trust creates norms of obligation and cooperation and minimizes transaction costs (Jones and George, 1998; Korczynski, 2000). Research also shows that norms of obligation and cooperation lead to both interpersonal and inter-organizational trust (Sandler, 1993; Barney and Hansen, 1994; Das and Teng, 1998; Jones and George, 1998; Rousseau et al., 1998). Also, strategies of consistent cooperative behavior influence all dimensions or systems of trust (Das and Teng, 1998; Jones and George, 1998; McKnight et al., 1998). Admittedly, the dynamic and cyclical nature of trust makes an understanding of its development somewhat elusive. But, a closer look at trust development shows that the long-term is built from the short-term, rather than vice versa (Oberschall and Leifer, 1986). Besides, if trust were a pre-requisite, then the introduction of partnering would not even be necessary in the first place. Therefore, trust is more a consequence of, than a means for, the achievement of cooperation (see also Katzenbach and Smith, 1993;

Abudayyeh, 1994; Albanese, 1994; Lazar, 2000; Wood and McDermott, 2001). 


\section{Contractual incentives}

The use of performance incentives in the underlying contracts between contracting parties has also been cited as a critical success factor for partnering. Research shows that incentives do drive behavior (e.g., Ashley and Workman, 1986; Kohn, 1993; Tyler and Blader, 2000). However, research also shows that their use can be problematic and sometimes even counterproductive. The discourse on performance incentives usually confounds firms with the managers representing them (see Bresnen and Marshall, 2000a; Bresnen and Marshall, 2000b). Agency theory, which underpins the use of performance incentives, assumes that agents will shirk unless their actions contribute directly to their own economic self-interest. Therefore, shirking can only be mitigated through monitoring combined with contracts (incorporating sanctioning and reward mechanisms) that appeal to their self-seeking nature (Simon, 1991). However, here the agent is a firm and not the manager(s) representing that firm. Even at the top executive levels of firms there is considerable opportunity for discrepancy between the goal of owners (i.e., profit) and the goals of managers (Oberschall and Leifer, 1986; Simon, 1991). No doubt, managers have an interest in the long-term success of their organizations. However, the link between such performance incentives and the mitigation of the pursuit of managerial short-term self-interest is, rather, indirect and tenuous (for an explication of this argument, see Simon, 1991; Kohn, 1993; Pfeffer, 1994, 1997; Tyler and Blader, 2000).

Most importantly, performance incentives can work against the objectives of the project organization. With managers making positional commitments to defend or protect the interests of their respective firms, performance incentives can lead to sub-optimal 
outcomes for the project. They encourage a myopic focus on the specified tasks that influence the outcomes they are tied to, reduce risk-taking behavior and, hence limit performance quality and innovation (Simon, 1991; Kohn, 1993; Pfeffer, 1997;

Thompson et al., 1998). Measurement problems further complicate the use of performance incentives on construction projects. Uncertainty means that a clear and precise definition of performance standards/ specifications in advance is both impossible and undesirable. Intense interdependence makes it difficult to isolate and measure to a reasonable level of accuracy each firm's contribution to an outcome or liability for a default. With complexity and uncertainty being the hallmarks of all but, perhaps, the simplest construction projects, even the most 'objective' indices of performance are at best inadequate and highly corruptible (Simon, 1991; Kohn, 1993; Fernie et al., 2006). Ashley and Workman (1986) found that although overall performance (quantity) was marginally greater with their use, contractual incentives created significantly more contractual disputes between the contracting parties. Thompson et al. (1998) concluded that rather than a means to unite the parties, contractual incentives serve as "a wedge to drive distance between them" (p.36).

The objective of contractual incentives ought to be to motivate the various project actors to identify with the project's objectives. Without prejudice to the individual preferences of clients or procuring agents, a project's objectives are best served if the incentive arrangement results in a sharing of, rather than merely transferring, motive. This underscores the famous principle of 'shared risks unify motives' (Barnes, 1981; Bower et al., 2002). The 'sharedness' of motive is affected by how responsibilities and risks are apportioned, the reimbursement and governance structures in place (Thompson et al., 
1998; Bower et al., 2002). This leads back to the central thesis of this paper: by facilitating the attainment of optimal contact factors, partnering creates a sense of superordinate identification with the project organization. The objective function for all managers is, therefore, the optimization of the project's objectives. This explains the move towards the use of 'partnering-friendly' contracts that emphasize the fairness of risk/reward arrangements. Some go a step further and seek to prescribe the behavior and relationship among the parties (e.g., ICE, 1993). Research also shows that judgments on the fairness of procedures experienced and outcomes received affect perceptions of status (or respect) and trust (Gaertner and Dovidio, 2000; Tyler and Blader, 2000; Kadefors, 2005). While the legal basis of some of the provisions of these contracts have been challenged (e.g., see Cox and Thompson, 1996) and their practical import is yet unknown, these contracts are indicative of articulated support for cooperation (see Anderson and West, 1998).

\section{Early involvement of ' partners'}

This facilitates the above-described group processes and is, perhaps, a common sense approach dictated by systems thinking and knowledge of the construction project value and cost cycles (Bower, 2002; Male, 2002).

\section{Partnering and strategic alliances}

Partnering and strategic alliances are forms of relational contracting (see Macneil, 1978;

Williamson, 1985; Bradach and Eccles, 1989; Rahman and Kumaraswamy, 2002).

However, there is a conceptual difference between them. Assuming a continuum exists of possible relational contracting arrangements (as suggested in Bennett and Jayes, 
1998; Thompson et al., 1998), although such a view has been argued to be misleading (see Bradach and Eccles, 1989), partnering and strategic alliances are the poles of this continuum. A strategic alliance is a long-term interorganizational arrangement for mutual benefit, which is based on equivalence and high complementarity (Kanter, 1994; Cox, 1996; Hampson and Kwok, 1997). Because of their long-term nature, strategic alliances facilitate interorganizational learning, which is important for the commitmentbuilding process and increases the chance of achieving optimal contact (Katzenbach and Smith, 1993; Pettigrew, 1998; Love et al., 2002). In other words, a strategic alliance is a cooperative relationship between parties when some shared expectation about the future (i.e. trust) exists. There is evidence of the existence of trust-based relationships in the construction industry between main and subcontractors (e.g., Eccles, 1981a; Hampson and Kwok, 1997; Kale and Arditi, 2001) and also between clients and main contractors (e.g., Tse, 1984; Loraine, 1994; Bennett and Jayes, 1998; Barlow, 2000).

However, the future is rarely pre-ordained. Instead, the future is built on the basis of past and present actions. As Oberschall and Leifer (1986: 248) put it: 'a lot of effort is required before there is an indefinite transaction future ahead to constrain exploitative behavior'. Asset specificity and uncertainty can grow out of such effort, rather than being present from the start, and facilitate a trust relationship. Many of the strategic alliances or term arrangements in the offshore construction sector grew out of many successful competitively let contracts, which themselves lasted several years (Loraine, 1994). This underlines the crucial role of partnering as a transformative mechanism through which such a future can be constructed (see Figure 1). Partnering provides a mechanism through which to foster cooperation in a project environment where trust is 
limited or non-existent. This favorable contact then increases the likelihood and attractiveness of future contact and, constitutes the foundation of a trust-based relationship (Albanese, 1994; Pettigrew, 1998; Spatz, 2000).

\section{Industry level cultural transformation}

The ultimate aim of most project managers is to motivate their workgroups to change or modify their behaviors in ways that will lead to and/or facilitate the achievement of the project's objectives. However, for others, e.g. governments and large clients, who are concerned that the construction industry as a whole is too adversarial and therefore needs to change, the goal extends beyond the needs of a single project to an effort to catalyze a cultural transformation. But some question how, if at all, partnering can transform the culture of construction (e.g., Bresnen and Marshall, 2000b; Fisher and Green, 2001). One of the major arguments is that behavioral change is not necessarily due to or indicative of a cultural transformation. However, behavioral change often precedes attitudinal change. The dissonance between new behavior and old prejudices is resolved by revising one's attitudes, which process also benefits from extended and/or repeated contact (Pettigrew, 1998). As cooperation between organizations ultimately reduces to cooperation between individual managers from the different organizations (Smith et al., 1995), it appears that the key question is whether or not contact effects generalize to other members not present in the project situation and also across different settings. 
According to Pettigrew's (1998) reformulated intergroup contact theory, three sequential strategies allow generalization of contact effects to the outgroup. These are decategorization (see Hewstone and Brown, 1986), salient categorization (see Brewer and Miller, 1984) and recategorization (see Gaertner et al., 1993). Decategorization reduces bias by diminishing the salience of original ingroup/outgroup categorizations. Recategorization results in a one-group identity or a superordinate (inclusive) identity that highlights the similarities among the interactants and thus obscures the "them-andus' boundary (Gaertner et al., 1993). These processes require a long-term perspective facilitative of individual and group learning (see also Kanter, 1994; Love et al., 2002). Progression through these three stages of categorization is not automatic and, recategorization into a single group is often not attained (Pettigrew, 1998). In the specific case of construction, recategorization into a single group may not even be desirable since the original organizational identities of workgroup members cannot be forsaken. As Gaertner et al. (1993) demonstrate, it is possible to maintain a dual representation in which both superordinate and original group identities are simultaneously salient.

Pettigrew (1997) found that intergroup friendship has the potential to invoke all the mediating processes required to achieve optimal intergroup contact. As a result, Pettigrew (1998) proposed a fifth condition for the contact hypothesis: friendship potential. This opportunity implies the potential for extended and/or repeated contact in a variety of business and social contexts in which the close interactions lead to selfdisclosure and other individualizing experiences (Pettigrew, 1998; Gaertner and Dovidio, 2000). The importance of close personal relationships in different sectors of 
economic life has been demonstrated by many studies (e.g., Granovetter, 1985; Bradach and Eccles, 1989; Phua and Rowlinson, 2004b). The importance of the time dimension to the group learning process makes optimal contact difficult to achieve within the lifespan of a single project (see Cook and Hancher, 1990; DeVilbiss and Leonard, 2000). However, the role of partnering in initiating and facilitating this commitment-building process is very significant. It creates the foundation on which the future is built and is a catalyst for change. There is also evidence from the partnering literature that projects that did not satisfy most of the essential contact conditions reported improved cooperation and where these were present, performance expectations were met or even exceeded. For many project managers, this is a significant achievement in itself in an industry where cooperation (and hence, good performance) is an aberration.

\section{Conclusions and directions for future research}

This paper has presented a model (see Figure 1) that provides conceptual-definitional clarity on partnering. The relevance of the key processes, tools and techniques involved in, and outcomes of, partnering as well as the link to cooperation and project performance have been discussed. By drawing on two related but separate lines of literature in social psychology, four essential factors for optimal cross-functional workgroup cooperation have been identified. The role of partnering as the transformative mechanism through which these essential factors are induced and nurtured has been explained and corroborated with evidence from the published literature on the concept. It is believed that direct testing of the model will be required before it can be fully validated and deployed. But even in this state, the model can 
clearly help project managers to focus their attention on the necessary aspects of workgroup processes that lead to high cooperation and good performance.

By clarifying the role and goals of partnering, the stage is set for a more focused and purposeful study of other key aspects of the concept. This model provides some useful indications on the direction of such research. While support for the relationships portrayed in the model is readily available, there is still a need to test the strengths of these relationships in the context of the overall model. Another reason why the model could benefit from some forms of direct testing is because some of the evidence on which these relationships have been determined falls outside the realm of construction, thus leaving open the question of their validity in the context of construction. One obvious limitation to direct testing, however, is the fact that the experimental nature of these study designs makes direct replication in construction management research almost impossible. Still, conceptual replication through correlational studies is still considered possible. The internal validity of any significant correlations is not an issue since the directions of causality have already been determined in these experimental designs.

Additional support is required for the link between partnering and the four essential factors hypothesized in the model. Empirical evidence of the link between the essential factors and cooperation is needed, although anecdotal support abounds. The same is true of the relationship between cooperation and project performance outcomes. Phua and Rowlinson (2004b) provide some support for this relationship in their grounded study of critical success factors for project success. However, their measure of cooperation taps 
only one dimension of the construct and other factors identified in their study confounded the cooperation effects. But even this limited measure of cooperation explained about $28 \%$ of the variability in the dependent variable 'project success', defined in terms of meeting budget, schedule and quality performance targets. More evidence is therefore required in this regard. Wagner (1995) provides partial support for the moderating effect of culture on cooperation, but Phua and Rowlinson (2004a) did not establish any such moderator role for culture. Therefore, some direct measure of the influence of culture on the hypothesized relationships in the model will be very useful. This can be considered in future research.

\section{Acknowledgments}

Grant No HKU/7011/02E from the Hong Kong Research Grants Council is gratefully acknowledged for facilitating the research reported here. Two anonymous reviewers contributed to the clarity and exposition of the arguments in this paper.

\section{References}

Abudayyeh, O. (1994) Partnering: a team building approach to quality construction management. J. Manage. Eng., 10(6), 26.

Albanese, R. (1994) Team-building process: key to better project results. J. Manage. Eng., 10(6), 36-44.

Allport, G.W. (1954) The nature of prejudice. Cambridge, Mass. :: Addison-Wesley. Anderson, N. and West, M. (1994) The personality of teamworking. Pers. Manage, 26(11), 81. 
Anderson, N.R. and West, M.A. (1998) Measuring climate for work group innovation: development and validation of the team climate inventory. J. Organ. Behave., 19(3), 235-258.

Anumba, C.J., Baugh, C. and Khalfan, M.M.A. (2002) Organisational structures to support concurrent engineering in construction. Ind. Manage. Data Syst., 102(5/6), 260-270.

Ashley, D.B. and Workman, B.W. (1986) Incentives in construction contracts, Austin, TX: Construction Industry Institute (CII).

Baiden, B.K., Price, A.D.F. and Dainty, A.R.J. (2006) The extent of team integration within construction projects. Int. J. Proj. Manage., 24(1), 13-23.

Barlow, J. (2000) Innovation and learning in complex offshore construction projects. Research Policy, 29(7-8), 973-989.

Barlow, J., Cohen, M., Jashapara, A. and Simpson, Y. (1997) Towards positive partnering. Bristol: The Policy Press.

Barnes, M. (1981) Project management by motivation. In: Proceedings of the PMI/ INTERNET 1981 Joint Symposium, Boston, 101-123.

Barney, J.B. and Hansen, M.H. (1994) Trustworthiness as a source of competitive advantage. Strateg. Manage. J., 15(Special Issue: Competitive Organisational Behaviour), 175-190.

Bayliss, R., Cheung, S.-O., Suen, H.C.H. and Wong, S.-P. (2004) Effective partnering tools in construction: A case study on MTRC TKE contract 604 in Hong Kong. Int. J. Proj. Manage., 22(3), 253-263.

Beach, R., Webster, M. and Campbell, K.M. (2005) An evaluation of partnership development in the construction industry. Int. J. Proj. Manage., 23(8), 611-621. 
Bennett, J. and Jayes, S. (1995) Trusting the team: the best practice guide to partnering in construction, Centre for Strategic Studies in Construction/ Reading Construction Forum, University of Reading.

Bennett, J. and Jayes, S. (1998) The Seven Pillars of Partnering: a guide to second generation partnering. Reading Construction Forum: Thomas Telford.

Bennett, J. and Baird, A. (2001) NEC and partnership : the guide to building winning teams. London: Thomas Telford.

Black, C., Akintoye, A. and Fitzgerald, E. (2000) Analysis of success factors and benefits of partnering in construction. Int. J. Proj. Manage., 18(6), 423-434.

Bower, D. (2002) Projects and project management. In: Smith, N.J. (Ed.), Engineering Project Management, 2nd edn., pp. 1-15. Oxford: Blackwell Science.

Bower, D. and Merna, A. (2002) Finding the optimal contractual arrangement for projects on process job sites. J. Manage. Eng., 18(1), 17-20.

Bower, D., Ashby, G., Gerald, K. and Smyk, W. (2002) Incentive mechanisms for project success. J. Manage. Eng., 18(1), 37-43.

Bradach, J.L. and Eccles, R.G. (1989) Price, authority, and trust: From ideal types to plural forms. Ann. Rev. Sociology, 15(1989), 97-118.

Bresnen, M. and Marshall, N. (2000a) Motivation, commitment and the use of incentives in partnerships and alliances. Constr. Manage. Econ., 18(5), 587-598.

Bresnen, M. and Marshall, N. (2000b) Partnering in construction: a critical review of issues, problems and dilemmas. Constr. Manage. Econ., 18(2), 229-237.

Bresnen, M. and Marshall, N. (2001) Understanding the diffusion and application of new management ideas in construction. Eng. Const. Arch. Manage., 8(5-6), 335345. 
Bresnen, M. and Marshall, N. (2002) The engineering or evolution of co-operation? A tale of two partnering projects. Int. J. Proj. Manage., 20(7), 497-505.

Brewer, M.B. and Miller, N. (1984) Beyond the contact hypothesis: theoretical perspectives on desegregation. In: Miller, N. and Brewer, M.B. (Eds.), Groups in contact: the psychology of desegregation, pp. 281-302. Orlando, FL: Academic Press.

Brooke, K.L. and Litwin, G.H. (1997) Mobilizing the partnering process. J. Manage. Eng., 13(4), 42-48.

Brown, J. (1994) Partnering to save troubled projects. J. Manage. Eng., 10(May/June), $22-25$.

Chan, A.P.C., Chan, D.W.M., Fan, L.C.N., Lam, P.T.I. and Yeung, J.F.Y. (2004) A comparative study of project partnering practices in Hong Kong. CD-ROM Full Report of the CII-HK Research Project, CII-HK Report No. 2, ISBN: 98898153-3-8, Hong Kong: Construction Industry Institute - Hong Kong (CII-HK).

Chan, A.P.C., Chan, D.W.M., Chiang, Y.H., Tang, B.S., Chan, E.H.W. and Ho, K.S.K. (2004) Exploring critical success factors for partnering in construction projects. J. Constr. Eng. Manage., 130(2), 188-198.

Cheng, E.W.L. and Li, H. (2001) Development of a conceptual model of construction partnering. Eng. Const. Arch. Manage., 8(4), 292-303.

Cheng, E.W.L., Li, H. and Love, P.E.D. (2000) Establishment of critical success factors for construction partnering. J. Manage. Eng., 16(2), 84-92.

Cheng, E.W.L., Li, H., Drew, D.S. and Yeung, N. (2001) Infrastructure of partnering for construction projects. J. Manage. Eng., 17(4), 229-237. 
Chow, L.J., Then, D. and Skitmore, M. (2005) Characteristics of teamwork in Singapore construction projects. J. Construct. Res., 6(1), 15-46

CII (1991) In Search of Partnering Excellence. CII Special publication, Austin, TX:

Construction Industry Institute, USA.

CIRC (2001) Construct for excellence, Hong Kong: Construction Industry Review

Committee

Conley, M.A. and Gregory, R.A. (1999) Partnering on small construction projects. $J$. Constr. Eng. Manage., 125(5), 320-324.

Cook, E.L. and Hancher, D.E. (1990) Partnering: Contracting for the future. J. Manage. Eng., 6(4), 431.

Cornes, D.L. (1996) The second edition of the new engineering contract. Int. Constr. Law Rev., 13(Part 1 January), 97-119.

Cowan, C., Gray, C. and Larson, E. (1992) Project partnering. Proj. Manage J., 23(4), 511.

Cox, A. (1996) Relational competence and strategic procurement management :

Towards an entrepreneurial and contractual theory of the firm. Eur. J. Purchas. Supply Manage., 2(1), 57-70.

Cox, A. and Thompson, I. (1996) Is the NEC going to succeed? Int. Constr. Law Rev., 13(Part 3 July), 327-337.

Crane, T.G., Felder, J.P., Thompson, P.J., Thompson, M.G. and Sanders, S.R. (1997) Partnering process model. J. Manage. Eng., 13(3), 57-63.

Crowley, L.G. and Karim, A. (1995) Conceptual model of partnering. J. Manage. Eng., 11(5), 33-39. 
Das, T.K. and Teng, B.-S. (1998) Between trust and control: developing confidence in partner cooperation in alliances. Acad. Manage. Rev., 23(3), 491-512.

Davis, P.R. (1999) Relationship marketing in the construction industry. AACE Int. Trans., 11.

DeVilbiss, C.E. and Leonard, P. (2000) Partnering is the foundation of a learning organisation. J. Manage. Eng., 16(4), 47-57.

Drew, S. and Coulson-Thomas, C. (1996) Transformation through teamwork: the path to the new organization? Manage. Decis., 34(1), 7-17.

Dubois, A. and Gadde, L.-E. (2002) The construction industry as a loosely coupled system: implications for productivity and innovation. Constr. Manage. Econ., 20(7), 621-631.

Eccles, R. (1981a) The quasifirm in the construction industry. J. Econ. Behav. Organ., 2(4), 335-357.

Eccles, R.G. (1981b) Bureaucratic versus craft administration: the relationship of market structure to the construction firm. Adm. Sci. Q., 26(3), 449-469.

ECI (1997) Partnering in the public sector: a toolkit for the implementation of post award, project specific partnering on construction projects, Loughborough: European Construction Institute (ECI).

Egan, J. (1998) Rethinking construction. London: HMSO.

Ellison, S.D. and Miller, D.W. (1995) Beyond ADR: working toward synergistic strategic partnership. J. Manage. Eng., 11(6), 44-54.

Fernie, S., Leiringer, R. and Thorpe, T. (2006) Change in construction: a critical perspective. Build. Res. Inf., 34(2), 91-103. 
Fisher, N. and Green, S. (2001) Partnering and the UK construction industry the first ten years-a review of the literature In: NAO (Ed.), Modernising Construction, pp. 58- 66 London: National Audit Office, UK.

Fisher, R.B. (2004) Partnering construction contracts: a conflict avoidance process. In: AACE International Transactions, CDR17.1-17.9.

Fleming, Q.W. and Koppelman, J.M. (1996) Integrated project development teams: another fad ... or a permanent change. Int. J. Proj. Manage., 14(3), 163-168.

Gaertner, S.L. and Dovidio, J.F. (2000) Reducing intergroup bias: the common ingroup identity model. Philadelphia, PA: Psychology Press.

Gaertner, S.L., Dovidio, J.F., Anastasio, P.A., Bachman, B.A. and Rust, M.C. (1993) The common ingroup identity model: recategorization and the reduction of intergroup bias. Eur. Rev. Soc. Psychol., 4, 1-26.

Gaertner, S.L., Dovidio, J.F., Banker, B.S., Houlette, M., Johnson, K.M. and McGlynn, E.A. (2000) Reducing intergroup conflict: from superordinate goals to decategorization, recategorization, and mutual differentiation. Group Dyn., 4(1), 98-114.

Gardiner, P.D. and Simmons, J.E.L. (1998) Conflict in small- and medium-sized projects: Case of partnering to the rescue. J. Manage. Eng., 14(1), 35-40.

Gidado, K.I. (1996) Project complexity: the focal point of construction production planning. Constr. Manage. Econ., 14(3), 213-225.

Glagola, C.R. and Sheedy, W.M. (2002) Partnering on defence contracts. J. Constr. Eng. Manage., 128(2), 127-138.

Granovetter, M. (1985) Economic Action and Social Structure: The Problem of Embeddedness. Am. J. Sociol., 91(3), 481-510. 
Gransberg, D.D., Reynolds, L., Boyd, J. and Dillon, W.D. (1999) Quantitative analysis of partnered project performance. J. Constr. Eng. Manage., 125(3), 161-166.

Green, S.D. (1999) Partnering: the propaganda of corporatism? J. Constr. Procure., 5(2), 177-186.

Halman, J.I.M. and Braks, B.F.M. (1999) Project alliancing in the offshore industry. Int. J. Proj. Manage., 17(2), 71-76.

Hampson, K.D. and Kwok, T. (1997) Strategic alliances in building construction: A tender evaluation tool for the public sector. J. Constr. Procure., 3(1), 28-41.

Hauck, A.J., Walker, D.H.T., Hampson, K.D. and Peters, R.J. (2004) Project alliancing at National Museum of Australia - collaborative process. J. Constr. Eng. Manage., 130(1), 143-152.

Hellard, R.B. (1995) Project partnering : principle and practice. London: Thomas Telford.

Hewstone, M. and Brown, R. (1986) Contact and conflict in intergroup encounters. Oxford: Blackwell.

Holti, R., Nicolini, D. and Smalley, M. (1999) Building down barriers. Prime contractor handbook of supply chain management, London: Defence Estates, UK.

ICE (1993) The New engineering contract. 1st ed. London: Thomas Telford for the Institution of Civil Engineers (ICE).

Ingram, H., Teare, R., Scheuing, E. and Armistead, C. (1997) A systems model of effective teamwork. TQM Mag., 9(2), 118-127.

Johnson, D.W. and Johnson, F.P. (2003) Joining together : group theory and group skills. 8th ed. Boston: Allyn and Bacon. 
Jones, G.R. and George, J.M. (1998) The experience and evolution of trust: implications for cooperation and teamwork Acad. Manage. Rev., 23(3), 531-546.

Kadefors, A. (2005) Fairness in interorganisational project relations: norms and strategies. Constr. Manage. Econ., 23(8), 871 - 878.

Kale, S. and Arditi, D. (2001) General contractors' relationships with subcontractors: a strategic asset. Constr. Manage. Econ., 19(5), 541-549.

Kanter, R.M. (1994) Collaborative advantage: the art of alliances. Harvard Bus. Rev., July - August, 96-106.

Katzenbach, J.R. and Smith, D.K. (1993) The discipline of teams. Harvard Bus. Rev., March - April, 111-120.

Kohn, A. (1993) Why incentive plans cannot work. Harvard Bus. Rev., SeptemberOctober, 54-63.

Koraltan, S.B. and Dikbas, A. (2002) An assessment of the applicability of partnering in the Turkish construction sector. Constr. Manage. Econ., 20(4), 315-321.

Korczynski, M. (2000) The political economy of trust J. Manage. Stud., 37(1), 1-21.

Kwan, A.Y. and Ofori, G. (2001) Chinese culture and successful implementation of partnering in Singapore's construction industry. Constr. Manage. Econ., 19(6), 619-632.

Lampman, R.J. and Dimeo, B.S. (1989) Team collaboration like playing ball. J. Real Estate Dev., 5(1), 56-62.

Larson, E. (1995) Project partnering: results of study of 280 construction projects. $J$. Manage. Eng., 11(2), 30-35.

Larson, E. and Drexler, J.A.J. (1997) Barriers to project partnering: Report from the firing line. Proj. Manage J., 28(1), 46-52. 
Lazar, F.D. (2000) Project partnering: improving the likelihood of win/win outcomes. $J$. Manage. Eng., 16(2), 71-83.

Lenard, D.J., Bowen-James, A., Thompson, M. and Anderson, L. (1996) Partnering models for success, Adelaide: Construction Industry Institute Australia (CIIA).

Li, H., Cheng, E.W.L. and Love, P.E.D. (2000) Partnering research in construction. Eng. Const. Arch. Manage., 7(1), 76-92.

Liu, A.M.M. and Fellows, R. (2001) An Eastern perspective on partnering. Eng. Const. Arch. Manage., 8(1), 9-19.

Locke, E.A. and Latham, G.P. (1990) A theory of goal setting \& task performance. Englewood Cliffs, N.J.: Prentice Hall.

Loraine, R.K. (1994) Project specific partnering. Eng. Const. Arch. Manage., 1(1), 5-16.

Love, P., Gunasekaran, A. and Li, H. (1998) Concurrent engineering: a strategy for procuring construction projects. Int. J. Proj. Manage., 16(6), 375-383.

Love, P.E.D., Irani, Z., Cheng, E. and Li, H. (2002) A model for supporting interorganizational relations in the supply chain. Eng. Const. Arch. Manage., 9(1), 215.

Love, S. (1997) Subcontractor partnering: I'll believe it when I see it. J. Manage. Eng., 13(5), 29-31.

Macneil, I.R. (1978) Contracts: adjustment of long-term economic relations under neoclassical and relational contract laws. Northwest. Univ. Law Rev., 72(6), 854965.

Male, S.P. (2002) Supply Chain Management. In: Smith, N.J. (Ed.), Engineering Project Management, 2nd edn., pp. 264-289. Oxford: Blackwell Science. 
Mathews, J., Tyler, A. and Thorpe, A. (1996) Pre-construction project partnering: developing the process. Eng. Const. Arch. Manage., 3(1\&2), 117-131.

McKnight, D.H., Cummings, L.L. and Chervany, N.L. (1998) Initial trust formation in new organizational relationships Acad. Manage. Rev., 23(3), 473-490.

Miles, R.S. (1996) Twenty-first century partnering and the role of ADR. J. Manage. Eng., 12(3), 45-55.

Miller, C.J.M., Packham, G.A. and Thomas, B.C. (2002) Harmonisation between main contractors and subcontractors: a prerequisite for lean construction? J. Construct. Res., 3(1), 67-82

Moore, C., Mosley, D. and Slagle, M. (1992) Partnering: guidelines for win-win project management Proj. Manage J., 23(1), 18-21.

Moore, D.R. and Dainty, A.R.J. (2001) Intra-team boundaries as inhibitors of performance improvement in UK design and build projects: a call for change. Constr. Manage. Econ., 19(6), 559-562

Mosley, D., Moore, C., Slagle, M. and Burns, D. (1991) Partnering in the construction industry: win-win strategic management in action. Natl. Prod. Rev., 10(3), 319325.

Motowidlo, S.J. and Van Scotter, J.R. (1994) Evidence that task performance should be distinguished from contextual performance. J. Appl. Psychol., 79(4), 475-480.

Naoum, S. (2003) An overview into the concept of partnering. Int. J. Proj. Manage., 21(1), 71-76.

Ng, S.T., Rose, T.M., Mak, M. and Chen, S.E. (2002) Problematic issues associated with project partnering - the contractor perspective. Int. J. Proj. Manage., 20(6), 437449. 
Nicolini, D. (2002) In search of 'project chemistry'. Constr. Manage. Econ., 20(2), 167 177.

Nyström, J. (2005) The definition of partnering as a Wittgenstein family-resemblance concept. Constr. Manage. Econ., 23(5), 473-481.

Oberschall, A. and Leifer, E.M. (1986) Efficiency and social institutions: uses and misuses of economic reasoning in sociology. Ann. Rev. Sociology, 12, 233-253.

Pettigrew, T.F. (1997) Generalised intergroup contact effects on prejudice Personality And Social Psychology Bulletin, 23(2), 173-185.

Pettigrew, T.F. (1998) Intergroup contact theory. Annu. Rev. Psychol., 69, 65-85.

Pfeffer, J. (1994) Competitive advantage through people. Cambridge, MA: Harvard University Press.

Pfeffer, J. (1997) New directions for organization theory : problems and prospects. New York: Oxford University Press.

Phua, F.T.T. (2004) The antecedents of co-operative behaviour among project team members: an alternative perspective on an old issue. Constr. Manage. Econ., 22(10), 1033-1045.

Phua, F.T.T. and Rowlinson, S. (2004a) Operationalising culture in construction management research: a social identity perspective in the Hong Kong context. Constr. Manage. Econ., 22(9), 913-925.

Phua, F.T.T. and Rowlinson, S. (2004b) How important is cooperation to construction project success? A grounded empirical quantification. Eng. Const. Arch. Manage., 11(1), 45-54. 
Pinto, M.B. and Pinto, J.K. (1990) Project team communication and cross-functional cooperation in new program development. J. Prod. Innov. Manage., 7(3), 200212.

Rahman, M.M. and Kumaraswamy, M.M. (2002) Joint risk management through transactionally efficient relational contracting. Constr. Manage. Econ., 20(1), 4554.

Reichers, A.E. and Schneider, B. (1990) Climate and culture: an evolution of constructs. In: Schneider, B. (Ed.), Organizational climate and culture, pp. 5-39. San Francisco, CA: Jossey-Bass.

Rockart, J.F. (1982) The changing role of the information systems executive: a critical success factors perspective. Sloan Manage. Rev., 24(1), 3-13.

Rousseau, D.M., Sitkin, S.B., Burt, R.S. and Camerer, C. (1998) Introduction to special topic forum: Not so different after all: a cross-discipline view of trust Acad. Manage. Rev., 23(3), 393-404.

Rowlinson, S., Cheung, F.Y.K., Simons, R. and Rafferty, A. (2006) Alliancing in Australia - no-litigation contracts: a tautology? J. Prof. Issues Eng. Educ. Pract., 132(1), 77-81.

Sandler, T. (1993) The economic theory of alliances: a survey. J. Confl. Resolut., 37(3), 446-483.

Schein, E.H. (1980) Organizational psychology. 3rd ed. Englewood Cliffs, N.J.: Prentice-Hall.

Schermerhorn, J.R., Hunt, J.G. and Osborn, R. (1998) Basic organizational behavior. 2nd ed. New York: J. Wiley. 
Schultzel, H.J. and Unruh, V.P. (1996) Successful partnering : fundamentals for project owners and contractors. New York: John Wiley \& Sons.

SFC (2003) The integration toolkit guide: integrated project team. Available at http://www.strategicforum.org.uk, London: Strategic Forum for Construction (SFC), UK.

Shaw, M.E. (1981) Group dynamics. 3rd ed. New York, NY: McGraw-Hill.

Sherif, M. and Sherif, C.W. (1966) Groups in harmony and tension : an integration of studies on intergroup relations. New York: Octagon Books.

Shirazi, B., Langford, D.A. and Rowlinson, S.M. (1996) Organizational structures in the construction industry. Constr. Manage. Econ., 14(3), 199-212.

Simon, H.A. (1991) Organizations and markets. J. Econ. Perspect., 5(2), 25-44.

Smith, K.G., Carroll, S.J. and Ashford, S.J. (1995) Intra- and interorganizational cooperation: toward a research agenda. Acad. Manage. J., 38(1), 7-23.

Spatz, D.M. (2000) Team-building in construction. Pract. Period. Struct. Des. Constr., 5(3), 93-105.

Syer, J. and Connolly, C. (1996) How teamwork works : the dynamics of effective team development. London ; New York: McGraw-Hill.

Sze, E., Kumaraswamy, M., Wong, T., Yeung, N. and Rahman, M. (2003) Weak links in 'partnering' supply chains? Consultants and subcontractors' views on project partnering. In: Ahmed, S.M., Ahmad, I., Tang, S.L. and Azhar, S. (Eds.), Proceedings of $2^{\text {nd }}$ International Conference on Construction in the 21st Century (CITC-II), Hong Kong, 108-113.

Tajfel, H. (1978) Differentiation between social groups : studies in the social psychology of intergroup relations. London :: Academic Press. 
Tajfel, H. (1982) Social psychology of intergroup relations. Annu. Rev. Psychol., 33, 139.

Tajfel, H. and Turner, J.C. (1979) An integrative theory of intergroup conflict. In: Austin, W.G. and Worchel, S. (Eds.), The social psychology of intergroup relations, pp. 33-47. Monterey, CA: Brooks/Cole.

Thomas, G. and Thomas, M. (2005) Construction partnering and integrated teamworking. Oxford: Blackwell.

Thompson, I., Cox, A. and Anderson, L. (1998) Contracting strategies for the project environment. Eur. J. Purchas. Supply Manage., 4(1), 31-41.

Thompson, P.J. and Sanders, S.R. (1998) Partnering continuum. J. Manage. Eng., 14(5), 73-78.

Todryk, L. (1990) The project manager as team builder: creating an effective team. Proj. Manage J., 21(4), 17-22.

Tse, K.-K. (1984) Marks \& Spencer : anatomy of Britain's most efficiently managed company. Oxford: Pergamon.

Turner, A. (1997) Building Procurement. 2nd ed. London: Macmillan Press Ltd.

Tyler, T.R. and Blader, S.L. (2000) Cooperation in groups: procedural justice, social identity and behavioural engagement. Philadelphia: Psychology Press.

Uher, T.E. (1999) Partnering performance in Australia. J. Constr. Procure., 5(2), 163176.

Wagner, J.A., III (1995) Studies of individualism-collectivism: effects on cooperation in groups. Acad. Manage. J., 38(1), 152-172. 
West, M.A. (1990) The social psychology of innovation in groups. In: West, M.A. and Farr, J.L. (Eds.), Innovation and creativity at work : psychological and organizational strategies, pp. 4-36. Chichester, England: Wiley.

Weston, D.C. and Gibson, G.E. (1993) Partnering-project performance in U.S. Army Corps of Engineers J. Manage. Eng., 9(4), 410-425.

Williamson, O.E. (1985) The Economic Institutions of Capitalism. New York: Free Press.

Wilner, D.M., Walkley, R. and Cook, S.W. (1955) Human relations in interracial housing: a study of the contact hypothesis. Minneapolis: University of Minneapolis Press.

Wilson Jr, R.A., Songer, A.D. and Diekmann, J. (1995) Partnering: more than a workshop, a catalyst for change. J. Manage. Eng., 11(5), 40-45.

Winch, G.M. (2000) Institutional reform in British construction: partnering and private finance. Build. Res. Inf., 28(2), 141-155.

Winch, G.M. (2003) How innovative is construction? Comparing aggregated data on construction innovation and other sectors - a case of apples and pears. Constr. Manage. Econ., 21(6), 651-654.

Wood, G. and McDermott, P. (2001) Building on trust: a co-operative approach to construction procurement. J. Constr. Procure., 7(2), 4-14. 


\section{Figure captions}

Figure 1: A model of partnering and its effects on project performance (adapted from Gaertner et al., 1993) 


\section{$\underset{\substack{\text { Causes/ Domitions } \\ \text { Conditions }}}{\rightarrow}$ Change/ Integration $\rightarrow$ Mediators $\rightarrow$ Consequences

\section{Cognitive/ affective \\ effects \\ Perceived group homogeneity \\ Perceived similarity to self \\ Trust \\ Re-categorization \\ ('I/them' to 'Us') \\ Positive affect \\ Empathetic concern \\ Favorable evaluations \\ Behavioral effects \\ Cooperation \\ Helping \\ Individualizing \\ behaviors individual group}

Equal status

Issue resolution/ escalation procedures

Periodic performance assessment

Training on problemsolving \& joint decision-making, e.g. resource dilemma games
Cooperative interaction

Authority support

\section{Previous experience \\ Affective priming Cognitive priming}

Improved performance Cost, quality, schedule Innovation 